\title{
Simple preparation of ${ }^{76} \mathrm{Br}$, ${ }^{123} \mathrm{I}$ and ${ }^{211} \mathrm{At}$ labeled 5-halo-2'-deoxyuridine
}

\author{
J. Koziorowski, ${ }^{1,2}$ R. Weinreich ${ }^{1 *}$ \\ 1 Institute for Medical Radiobiology, Paul Scherrer Institute, CH.5232 Villigen PSI, Switzerland \\ ${ }^{2}$ Institute of Chemistry, Department of Organic Chemistry, Box 531, S-751 21 Uppsala, Sweden
}

(Received January 20, 1997)

A fast and easy method for the preparation of radiolabeled 5 -halo- 2 -deoxyuridine (halo $=\left[{ }^{76} \mathrm{Br}\right],\left[{ }^{123}\right]$ and $\left[{ }^{211}\right.$ At $]$ ) is presented. Labeling is accomplished by oxidation of the halogenide with Iodogen for $\left[{ }^{123} \mathrm{I}\right]$ and $\left[{ }^{211} \mathrm{At}\right]$, and Chloramine- $\mathrm{T}(\mathrm{CAT})$ for $\left[{ }^{76} \mathrm{Br}\right]$ followed by halodestannylation of 5-trimethylstannyl-2'-deoxyuridine (TMSUdR). The reaction takes 1 minute giving $>90 \%$ yield for all three halogens.

\section{Introduction}

The radiolabeled 5-bromo/iodo/astato-2'-deoxyuridines $\left(\left[{ }^{6} \mathrm{Br}\right] \mathrm{BrUdR},\left[{ }^{123}\right] \mathrm{IUdR},\left[{ }^{211} \mathrm{At}\right] \mathrm{AtUdR}\right)$ are thymidine (TdR) analogs where the 5-methyl group has been replaced with the above mentioned nuclides. Due to their similarity with TdR they are phosphorylated and incorporated into the DNA of proliferating cells in S-phase. Furthermore, as a result of the different decay properties of the three radiohalogens, the corresponding 5-halo-2'-deoxyuridine will be suitable for various applications: ${ }^{76} \mathrm{Br}$ has a 16.1 -hour half-life and decays emitting $\beta^{+}$-radiation $(57 \%)$ of various energies, ${ }^{123}$ I presents a 13.1 -hour half-life, mainly (83\%) emitting $159 \mathrm{keV} \gamma$-radiation. Finally, the 7.2-hour half-life $\alpha$-particle emitter ${ }^{211} \mathrm{At}$, displays two decay branches where the first produces (42\%) $5.87 \mathrm{MeV} \alpha$-particles and the second $(58 \%)$ leads to ${ }^{211}$ Po by electron capture, with 0.52 second half-life, which decays by the emission of $7.45 \mathrm{MeV}$ $\alpha$-particles. Whereas 5-[211 At]astato-2'-deoxyuridine has potential as an endoradiotherapeutic agent, ${ }^{1}$ both $5-\left[{ }^{6} \mathrm{Br}\right]$ bromo- and $5-\left[{ }^{123} \mathrm{I}\right]$ iodo- $2^{\prime}$-deoxyuridine possess properties making them suitable for the measurement of cell proliferation by imaging, in diagnostic oncology.,3 Herein, we report a simple method for the preparation of 5-trimethylstannyl-2'-deoxyuridine (TMSUdR), and the subsequent labeling with $\left[{ }^{76} \mathrm{Br}\right],\left[{ }^{123} \mathrm{I}\right]$ and $\left[{ }^{211} \mathrm{At}\right]$.

\section{Experimental}

\section{General}

The radionuclides were all produced at the Paul Scherrer Institute (PSI) via the following nuclear reactions:

$$
\begin{aligned}
& { }^{\text {nat }} \mathrm{Br}(\mathrm{p}, \mathrm{m})^{76} \mathrm{Kr} \rightarrow{ }^{76} \mathrm{Br} \quad E_{p}=72 \mathrm{MeV} \\
& { }^{127} \mathrm{I}(\mathrm{p}, 5 \mathrm{n})^{123} \mathrm{Xe} \rightarrow{ }^{123} \mathrm{I} \quad E_{p}=72 \mathrm{MeV} \\
& { }^{209} \mathrm{Bi}(\alpha, 2 \mathrm{n}){ }^{211} \mathrm{At} \quad E_{\alpha}=28 \mathrm{MeV}
\end{aligned}
$$

All chemicals except Iodogen, which was purchased from Pierce, were purchased from Fluka and used without further purification. 1H NMR spectra were recorded on a Varian Gemini $2000300 \mathrm{MHz}$ spectrometer. HPLC was conducted using a Waters 501 pump, a Waters 440 fixed-wavelength u.v. detector $(254 \mathrm{~nm})$, and a $\mathrm{NaI}(\mathrm{TI})$ crystal detector. HPLC analyses were performed on a C-18 $(10 \mu \mathrm{m} ; 4.6 \mathrm{~mm} \times 250 \mathrm{~mm})$ column eluted with $80: 20$ ( $\mathrm{v}: \mathrm{v}$ ) water : methanol at $1 \mathrm{ml} / \mathrm{min}$ flow rate. TLC was carried out on precoated silica gel $60 \mathrm{~F}_{254}$ on glass (Merck), with $80: 20(\mathrm{v}: \mathrm{v})$ dichloromethane : methanol as mobile phase. The TLC-plates were examined on an Berthold gas-flow scanner. Preparative column flash chromatography was accomplished with Silica gel 60 , 230-400 mesh ASTM (Merck).

\section{Preparation of 5-trimethylstannyl-2'-deoxyuridine (TMSUdR)}

5-Trimethylstannyl-2'-deoxyuridine was prepared using a slightly modified procedure of WigERINCK et al. ${ }^{4}$ A mixture of IUdR ( $1 \mathrm{~g}, 2.8 \mathrm{mmol})$, hexamethyldistannane $(1.3 \mathrm{ml}$, $2 \mathrm{~g}, 6.1 \mathrm{mmol}$ ) and bis(triphenylphosphine)palladium(II)dichloride $(100 \mathrm{mg})$ in anhydrous 1.4-dioxane $(50 \mathrm{ml})$ was stirred at $60^{\circ} \mathrm{C}$ for 2 hours under an atmosphere of dry nitrogen. After evaporation of dioxane the residue was dissolved in acetonitrile and washed several times with cyclohexane to remove the tin residue. The acetonitrile solution was filtered, the solvent removed in vacuum and the crude product was purified by flash chromatography using a dichloromethane : methanol gradient (100\% dichloromethane $\rightarrow 90 \%$ dichloromethane : $10 \%$ methanol) to yield $0.62 \mathrm{~g}, 57 \%$ of TMSUdR as white translucent crystals. ${ }^{1} \mathrm{H}$ NMR (DMSO- $\mathrm{d}_{6}$ ) data were in agreement with a previous report: $^{4} \delta 0.72\left(\mathrm{~s}, 9 \mathrm{H}, \mathrm{Me}_{3} \mathrm{Sn}\right), 2.62(\mathrm{~m}, 1 \mathrm{H}, \mathrm{H}-2), 4.08(\mathrm{t}$, $\left.2 \mathrm{H}, \mathrm{H}-5^{\prime}\right) 4.31$ (m, $1 \mathrm{H}, \mathrm{H}-4$ ), 4.78 (m, $\left.1 \mathrm{H}, \mathrm{H}-3\right)$ ), 5.48 (t, $\left.1 \mathrm{H}, 5^{\prime}-\mathrm{OH}\right), 5.72$ (d, $\left.1 \mathrm{H}, 3^{\prime}-\mathrm{OH}\right), 6.70\left(\mathrm{t}, 1 \mathrm{H}, \mathrm{H}-1^{\prime}\right), 8.15$ (s, $1 \mathrm{H}, \mathrm{H}-6)$.

*Author for correspondence. 
J. KozIorowsKa, R. WEINREICH: SIMPLE PREPARATION of ${ }^{76} \mathrm{BR},{ }^{123_{\text {I AND }}}{ }^{211}$ AT

Preparation of 5-I ${ }^{123}$ IJiodo-

and 5-1 ${ }^{21}$ At Jastato-2'-deoxyuridine

$10 \mu \mathrm{l}$ of a lodogen stock solution $(1 \mathrm{mg} / 1 \mathrm{ml}$ in dry dichloromethane) was placed in a $0.3 \mathrm{ml}$ Reacti-Vial (Pierce). The solvent was evaporated by a slow stream of dry nitrogen, leaving a thin coat of lodogen. $10 \mu \mathrm{l}$ of an aqueous TMSUdR solution $(1 \mathrm{mg} / \mathrm{ml})$ was added followed by $10 \mu$ of either $\left[{ }^{123} \mathrm{I}\right]$-iodide, no-carrier added (n.c.a.) or [ ${ }^{211} \mathrm{At}$-astatide (n.c.a.) in a $0.1 \mathrm{M}$ sodium chloride $(0.1 \mathrm{M}$ phosphate buffer $\mathrm{pH}$ 7. The reaction mixture was vortexed for 1 minute yielding $>90 \%$ of the corresponding product. Radio TLC $R_{f}$ : $\mathrm{At}^{-} 0.1$, AtUdR $0.55, \mathrm{I}^{-} 0.2$, IUdR 0.55 . HPLC retention times $\left(R_{t}\right): \mathrm{I}^{-} 4 \mathrm{~min}, \mathrm{UdR} 5.5 \mathrm{~min}, \mathrm{IUdR}$ $9 \mathrm{~min}$.

\section{Preparation of 5- $\mathrm{l}^{76} \mathrm{Br} / \mathrm{bromo-2}$-deoxyuridine}

To a $0.3 \mathrm{ml}$ Reacti-Vial (Pierce) was pipetted $10 \mu \mathrm{l}$ $\left[{ }^{76} \mathrm{Br}\right]$ bromide (n.c.a.) in a $0.1 \mathrm{M}$ sodium chloride/0.1M phosphate buffer $\mathrm{pH} 7$ solution and $10 \mu \mathrm{l}$ of an aqueous TMSUdR solution $(1 \mathrm{mg} / \mathrm{ml})$ followed by $10 \mu \mathrm{l}$ of a CAT solution $(2 \mathrm{mg} / \mathrm{ml}$ in $0.1 \mathrm{M} \mathrm{pH} 7$ phosphate buffer). The reaction mixture was vortexed for $1 \mathrm{~min}$ yielding $>90 \%$ of the product. Radio TLC $R_{i}: \mathrm{Br}^{-} 0.2, \mathrm{BrUdR} 0.55$. HPLC $R_{r} \mathrm{Br}^{-4} \mathrm{~min}, \mathrm{UdR} 5.5 \mathrm{~min}, \mathrm{BrUdR} 9 \mathrm{~min}$.

\section{Results and discussion}

In the first report where crystalline TMSUdR was obtained, ${ }^{1}$ the route involved a two-step purification including silica gel preparative TLC. Our approach is a one-step method, and consequently presents a less time-consuming and circumstantial route to obtain TMSUdR in solid form. Both the 5-[ ${ }^{123}$ I]iodo- and 5-[ ${ }^{211}$ At]astato-2'-deoxyuridine syntheses have been described. 1.5 Our approach did not improve the yield, but the use of lodogen-coated vials which can be stored for long times versus a heterogeneous mixture reaction, depending on the freshness of the non-stable oxidizing reagent should improve reproducibility and reliability. Bromodestannylation was accomplished using the well-known oxidant CAT, while attempts to use iodogen as oxidant were unsuccessful. Some more recent reports on the preparation of 5-radiobromo-2'-deoxyuridine ${ }^{6,7}$ give $50-65 \%$ radiochemical yield, while an earlier investigation ${ }^{8}$ describes a labeling technique producing $80-90 \%$ radiochemical yield of the radiobromonucleoside: bromodestannylation is less laborious than the three-step procedure described in the last mentioned publication, and gives slightly higher yields. We found that radiolabeled 5-halo-2'-deoxyuridine $\left(\left[{ }^{76} \mathrm{Br}\right],\left[{ }^{123} \mathrm{I}\right]\right.$ and $\left.\left[{ }^{211} \mathrm{At}\right]\right)$ can be prepared in a simple and rapid way by destannylation of TMSUdR. The simplicity can contribute to a reliable production in a clinical situation, while the short labeling time might decrease radiolysis and reduce personnel dose.

The authors are grateful to Prof. B. LaRsson for his continuing interest and stimulating discussions, Mrs. Nathalie REMY, Radiophammacy, PSI, for providing samples of ${ }^{76} \mathrm{Br}$ and ${ }^{123} \mathrm{I}$, and the Swiss National Fund (No. $3100-045665.95 / 1$ ) for financial support.

\section{References}

1. G. Vaidyanathan, R. H. LaRsen, M. R. Zalutsky, Cancer Res., 56 (1996) 1204.

2. K. Harrison, G. V. Dalrymple, J. Baranowska-Kortylewicz, M. H. Schneiderman, K. Holdeman, P. Leichner, S. C. Augustine, D. JACoBson, J. Nucl. Med., 35 (Suppl.) (1994) p. 144.

3. J.-E. RYSER, I. NOVAK-HOFer, N. RÉmY, L. WYER, R. WEDREJCH, U. Roelcke, B. Kaser-HotZ, P. BläUensten, Annual Repont 1995, Annex II, PSI Life Sciences and Institute for Medical Radiobiology, Newsletter 1995 , p. 30.

4. P. Wigerinck, L. Kerremans, P. Claes, R. Snoeck, P. Maudgal, E. De Clero, P. Herdewtin, J. Med. Chem., 36 (1994) 538.

5. C. F. Foulon, Y. Z. Zhang, S. J. Adelsten, A. I. Kassis, Appl. Radiat. Isot., 46 (1995) 1039.

6. K. D. McElvany, M. J. Welch, J. A. Katzenellenbogen, S. G. Senderoff, G. E. Bentley, P. M. Grant, Int. J. Appl. Radiation Isotopes, 32 (1981) 411 .

7. R. C. Mease, S. J. Gatley, A. M. Friedman, J. Label. Compd. Radiopharm., 29 (1990) 393.

8. H. Lundevist, P. Malmborg, B. Langstrom, S. N. Chingama, Int. J. Appl. Radiation Isotopes, 30 (1979) 39. 